\title{
PERINEAL COLOSTOMY: AN ALTERNATIVE TO AVOID PERMANENT ABDOMINAL COLOSTOMY: OPERATIVE TECHNIQUE, RESULTS AND REFLECTION
}

\author{
Colostomia perineal: uma alternativa para evitar a colostomia abdominal definitiva: técnica operatória, resultados e reflexão
}

\author{
Alcino Lázaro da SILVA, Johnny HAYCK, Beatriz DEOTI
}

From the Departamento de Cirurgia Faculdade de Medicina, Universidade Federal de Minas Gerais and Associação dos Amigos Mário Penna - Unidade Luxemburgo (Surgery Service, Clinical Hospital, Federal University of Minas Gerais and Association of Friends Mário Penna, Luxemburgo unit), Belo Horizonte (MG), Brazil.

HEADINGS - Colorectal neoplasm. Amputation. Colostomy. Quality of life. Therapeutic irrigation.

\section{Correspondence:}

Alcino Lázaro da Silva

E-mail: bardesiro@terra.com.br

Financial source: none

Conflicts of interest: none

Received for publication: 20/05/2014 Accepted for publication: 19/08/2014

DESCRITORES - Neoplasias colorretais Amputação. Colostomia. Qualidade de vida. Irrigação terapêutica.
ABSTRACT - Background: The most common injury to indicate definitive stoma is rectal cancer. Despite advances in surgical treatment, the abdominoperineal resection is still the most effective operation in radical treatment of malignancies of the distal rectum invading the sphincter and anal canal. Even with all the effort that surgeons have to preserve anal sphincters, abdominoperineal amputation is still indicated, and a definitive abdominal colostomy is necessary. This surgery requires patients to live with a definitive abdominal colostomy, which is a condition that modify body image, is not without morbidity and has great impact on the quality of life. Aim: To evaluate the technique of abdominoperineal amputation with perineal colostomy with irrigation as an alternative to permanent abdominal colostomy. Method: Retrospective analysis of medical records of 55 patients underwent abdominoperineal resection of the rectum with perineal colostomy in the period 1989-2010. Results: The mean age was 58 years, $40 \%$ men and $60 \%$ women. In $94.5 \%$ of patients the indication for surgery was for cancer of the rectum. In some patients were made three valves, other two valves and in the remaining no valve at all. Complications were: mucosal prolapse, necrosis of the lowered segment and stenosis. Conclusion: The abdominoperineal amputation with perineal colostomy is a good therapeutic option in the armamentarium of the surgical treatment of rectal cancer.

RESUMO - Racional: O câncer de reto é o agravo mais frequente para a indicação do estoma abdominal definitivo. Apesar dos avanços no tratamento cirúrgico, a amputação abdominoperineal ainda é a operação indicada mais efetiva nesta indicação com invasão de esfíncter e de canal anal, o que impõe aos pacientes colostomia abdominal definitiva, condição que altera a imagem corporal e grande repercussão na qualidade de vida. Objetivo: Avaliar a técnica de amputação abdominoperineal mais colostomia perineal com irrigação como alternativa à colostomia abdominal definitiva. Método: Análise retrospectiva de prontuário médico de cinquenta e cinco pacientes submetidos à amputação abdominoperineal do reto mais colostomia perineal no período de 1989 a 2010. Resultados: A média de idade foi de 58 anos sendo $40 \%$ em homens e $60 \%$ em mulheres. Em $94,5 \%$ dos pacientes a indicação cirúrgica foi por câncer de reto. Em alguns foram confeccionadas três válvulas, em outros duas e nos demais não foi confeccionada nenhuma válvula. As complicações foram: prolapso mucoso, necrose do segmento abaixado e estenose. Conclusão: A técnica de amputação abdominoperineal mais colostomia perineal é boa opção terapêutica no arsenal do tratamento cirúrgico do câncer de reto.

INTRODUCTION

istorically, after the first successful excision of the rectum made by Lisfranc in 1826 by perineal posed the problem of conservation of sphincter function avoiding permanent colostomy. Several authors have presented their proposals for rebuilding the gut, not always managing to reconcile radical treatment with neoanal function rehabilitation.

In 1908, Ernest Miles presented the reasons for radical amputation based on the routes of lymphatic spread of rectal cancer and its principles. His technique has spread so that the problems of conservation and restoration of sphincter bowel became secondary plan. There was a general impression that the conservation of the sphincters compromise the radicality of operation with consequent reduction of survival ${ }^{17}$.

Even with all the effort that surgeons have done to preserve a growing number of anal sphincters, subsidized by the advancement of technology, with the previous low performing resections, abdominoperineal amputation is still indicated, and a permanent abdominal colostomy is required ${ }^{10}$. On now it seems that is still far from a technique proscribed as published in the literature after the encouraging results of total mesorectal excision: "an endangered operation".

Lázaro da Silva participated in a research line in smal intestine ${ }^{11}$ and proposed this study in large intestine $e^{12,16}$ and joined the group of authors seeking options to avoid permanent colostomy $y^{8,19,7,1}$. In 1991 he published his experience: abdominoperineal amputation modified, more abdominoperineal amputation with perineal colostomy and irrigation. The goal was to avoid permanent abdominal colostomy keeping the radical treatment for lesions that warrant resection anal sphincter ${ }^{11,12,16,13,14,15}$.

The author commented: "without taking sides [...] we must do everything to avoid a colostomy [...] when you live in a contemporary world where the worship is a physical reality. Reality 
so striking that women are increasingly exposing physically while men turn their concerns and attitudes towards physical beauty of its exterior. Are contemporary situations that they can not deny values or support, rather than criticism"16.

The aim of this study was to evaluate the technique of abdominoperineal amputation with perineal colostomy irrigation as an alternative to definitive abdominal colostomy through a survey of 55 patients who underwent abdominoperineal resection with perineal colostomy in the period 1989-2010.

\section{METHODS}

\section{Operation}

The abdominoperineal amputation of the rectum is the standard surgery with removal of a cylindrical piece with mesorectal integrity. Systematic mobilization of the left colon and ligation of the inferior mesenteric artery and vein, need great care with the marginal arcade. Three seromyotomies section consisting of serosa, longitudinal and circular circumferential $\left(360^{\circ}\right)$ layers until the protrusion of the mucosa followed by invaginating sutures (Figures 1 and 2), are done. The manufacture of the valves begins 10 $\mathrm{cm}$ cranial to the perineal colostomy, lying $10 \mathrm{~cm}$ from each other (Figure 3). Next step is to take place the lowering of the colon and its sutured at the perineal skin edge (Figures 4A, 4B, 4C and 4D). If the tumor imposes the need for removal of a greater amount of skin, one can run a skin flap, "Z"-plasty, which facilitates the approximation of the skin edges with the edge of the stoma (Figure 5), or let the granulation occupy the empty space in the pelvis .
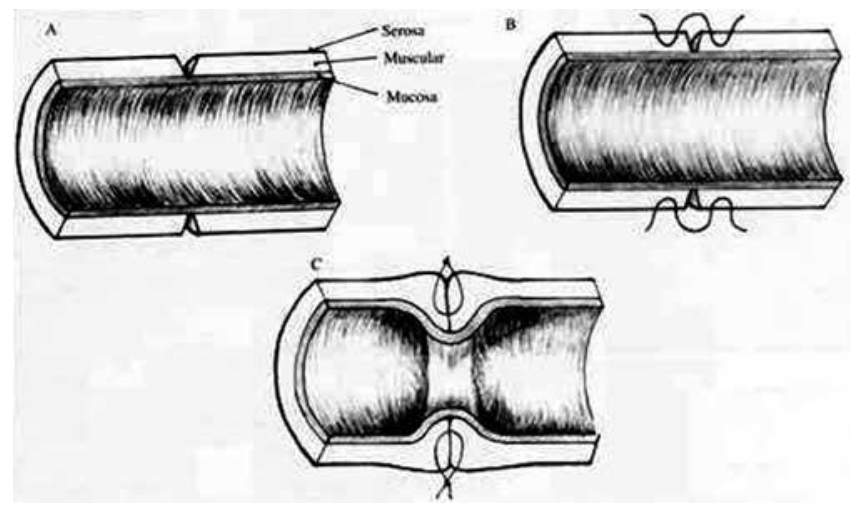

FIGURE 1 - Schematic drawing illustrating the circumferential seromiotomy $(A)$ and the seromuscular sutures invaginating the mucosa $(B, C)^{24}$

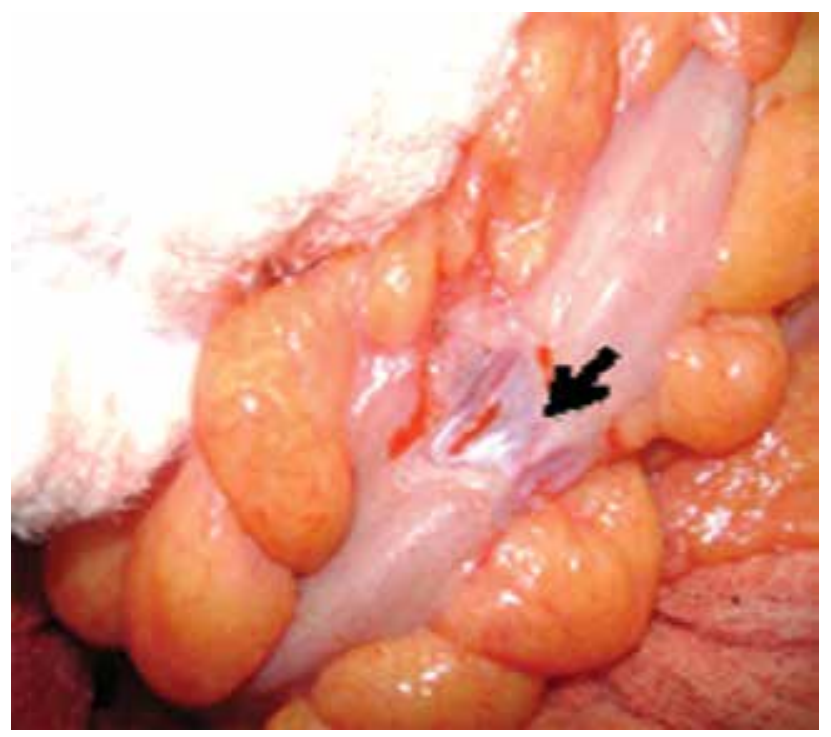

FIGURE 2 - Seromiotomy with mucosal exposure in lowered colon segment (arrow)

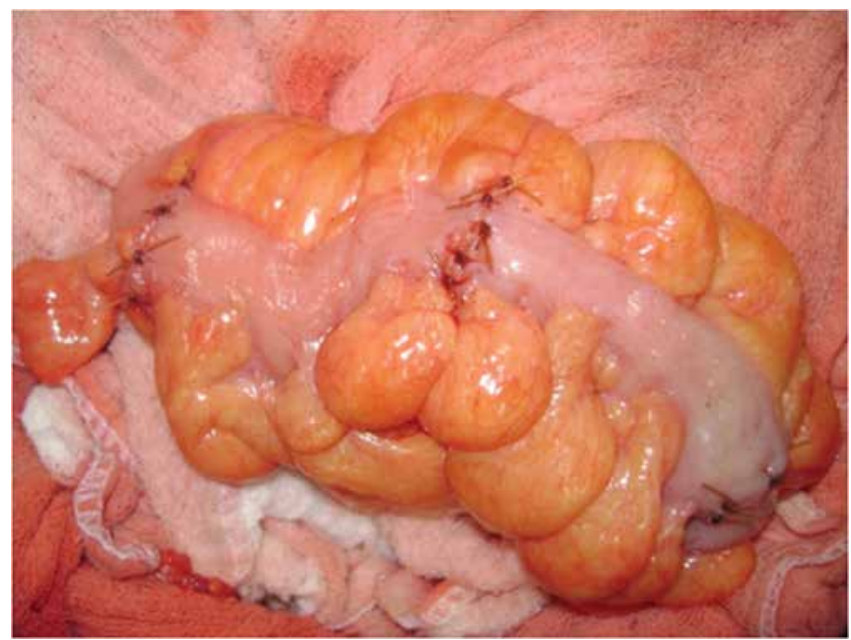

FIGURE 3 - Three seromiotomies (valves made at lowered colon) $10 \mathrm{~cm}$ distally from one another
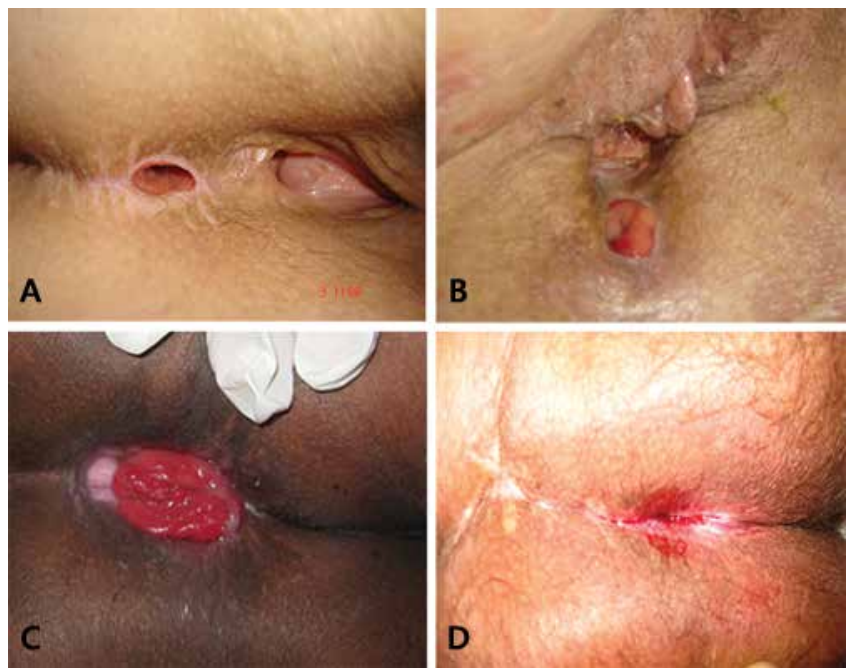

FIGURE 4 - A) Patient aged 37 with perineal colostomy for five years and six months; B) 71 year old patient with perineal colostomy for 20 years; $C$ ) patient of 49 years with perineal colostomy for four years and seven months showing mild prolapse and absence of dermatitis; D) rotation skin flap (black arrow) to cover the defect of sacrectomy with perineal colostomy stenosis (blue arrow) in perineal colostomy after four years and five months.

Patient's continence is made by autoirrigation. They are trained to make a perineal colostomy irrigation in with current warm water. At first, each $3^{\text {rd }}$ day. Over time, each patient sets the cleaning interval according to his need and well being.

\section{RESULTS}

The average age was 58 years (38-80), $40 \%(n=22)$ were male and $60 \%(n=33)$ were female. In $94.5 \%(n=52)$ of the patients the indication for surgery was for cancer of the rectum, at $3.63 \%(n=2)$ was for cancer of the anus and $1.81 \%(n=1)$ for severe perineal Crohn's disease. As for the height of the tumor in relation to the anal verge: $40.38 \%$ was at $2 \mathrm{~cm} ; 15 \%, 3 \mathrm{~cm} ; 1.92 \%, 4 \mathrm{~cm} ; 5.76 \%, 5 \mathrm{~cm} ; 1.92 \%$, $7 \mathrm{~cm} ; 3.84 \%$, without notes in the medical record. As for the number of valves, three valves were made in $51 \%$ of patients and two in $18 \%$; in $18 \%$ no valve was made and $13 \%$ had no notes in the medical record. Complications 
were: mucosal prolapse in $10.9 \%$ who were all corrected with simple perineal resection for access and local anesthesia; two necroses of the colon segment put down, and in one patient was re-done new colon lowering, and in another patient was left with permanent colostomy at right position, because the necrosis hit the hepatic angle; two stenoses of the perineal stoma with local resection wuth resuture and ostomy were found; one stenosis of the vaginal introitus for suspected recurrence; one incisional hernia; one intraoperative bleeding controlled; no deaths in the immediate postoperative period; three dehiscence of the perineal colostomy with primary suture, and a bowel obstruction after one year of surgery with patient's death.

As for irrigation, it is a viable self-care, with varying time periods according to the need and condition of the patient. The range of irrigation was varied between patients daily, $2 / 2$ days to $5 / 5$ days, and on alternate days. One patient preferred to evacuate two to three times per day doing abdominal press instead of the irrigation.

It was impossible to collect data of survival and quality of life due to the age of patients and the difficulty in locating them.

\section{DISCUSSION}

Radical resection of the primary tumor including regional lymphnodes, operation with preservation of nerves and perineal surgery continent with anal sphincter preservation are pillars of modern surgical therapy for rectal cancer. A low anterior resection, including total mesorectal excision is the treatment of choice for cancer of the rectum or lower. The abdominoperineal resection with permanent colostomy is usually recommended for low rectal cancer with invasion of the sphincter complex or insufficient sphincter ${ }^{2}$

The disease-free longer survival as a result of advances in surgical technique, adjuvant therapy and technologies used in the management of patients, reinforces the importance of using quality of life as a measure to evaluate the treatments performed, especially in terms respect to functional aspects ${ }^{3,22}$.

The intestinal stoma is a strong negative factor in emotional and physical impact to the people who have it, as it represent not only changes in body image and self-esteem, but also the bad functional aspects associated to it. Thus, there is a need to monitor and try to rehabilitate patients ostomatized through specific care, such as autoirrigation, enabling them to better bowel control, which reflects on their quality of life ${ }^{2}$

As many studies suggest that patients with a stoma have a poorer quality of life than those without it, and as many patients find that life with a permanent colostomy is unacceptable, the limits of operation preserving continence has been expanded in recent decades. Advances in surgical technique with the introduction of inter-sphincteric resection and better understanding of the necessary safety in distal margins, resulted in greater tendency of sphincter preservation even very low tumors. This was based on the assumption that the quality of life could be better to avoid permanent stoma in low rectal cancer ${ }^{22}$.

Studies show improved quality of life for people in the use of methods of bowel control. A sample of colostomy patients in use of the method of bowel control as autoirrigation, had higher average scores than those obtained by patients who did not use it with significant difference $(p<0.001)$, obtained in all domains in the overall quality of colostomized patients $\mathrm{s}^{4,23}$.

The perineal colostomy can be included in the arsenal of colorectal surgery by providing neoanal functional rehabilitation to promote control of intestinal contents. The most relevant factor is to avoid abdominal permanent colostomy.

Stand out as the technical advantages: avoids abdominal colostomy; fills the pelvis; preserves the oncological treatment character because it does not interfere with block excision of pelvic tissues; scar repair is done around a quarter of the time; the secretion of colonic mucosa is small in perineal colostomy or does not exist, because there is a partial occlusion and minimal skin externalization; under the social point of view, provides better conditions of living than that using bag; continence is relative, the patient can plan his care according to his convenience; avoids a low anastomosis; prevents pelvic sepsis with ileostomy; rebuilds the vagina in its sidewalls; the bladder function is effective; the perineal healing is faster; prevents colostomic and perineal hernia; saves fundings, because it eliminates the use of colostomy bag and treatment of dermatitis; does not predispose to infection or vaginosis and urinary tract and has no smell or sound of gas; does not require routine flap rotation so no increasing morbidity of the operation; may be performed in patients who underwent neoadjuvant therapy and adjuvant one is not delay if indicated. In daily life, when a surgeon is prepared technically, when offers this option to the patients they prefer this method to the abdominal wall permanent colostomy $4,10,9,13,14,15,25,26$.

The valve made can not prevent all the mechanisms of motility. Probably makes them less effective and uncoordinated, so it is not obstructive but contender. It slows the transit time of the intestinal contents and increases the contact time of nutrients with the mucosa, resulting in stasis and dilation, with low clinic effect ${ }^{21,24}$.

Important studies in recent decades have shown that it is possible to reproduce the technique in an animal model. Making seromiotomy generates partial secondary stenosis, forming a fibrous ring, with elevation of the mucosa toward the lumen, with discontinuation of the longitudinal and transverse muscles. Clinical, radiological, histopathological and immunohistochemical analysis raised the possibility that the section of the muscle layer, accompanied by section of plexus of Auerbach, undermine the impulse propagation by surgical denervation. Morphology, distension of the colon and histological features, for the presence of fibrosis at the site of seromiotomy, confirmed that the partial stenosis obtained with sutures and its effects are responsible for the intraluminar contention ${ }^{25}$ mechanism $6,20,5,18$.

Irrigation is a desirable self-care. It is a mechanical method for the regulation of intestinal activity by washing the intestine through the stoma. Its purpose is to adapt the bowel to work more regularly with day range variable, which provides the patient with an ostomy free period of concern $^{16,4,24,18}$.

In this study, the great regret was not getting the data collection of all the variables considered important: quality of life and evolution of the perineal colostomy.

Were followed patients with at least three years and maximum 20 years with perineal colostomy. The ones still alive made good testimonies that stimulate to continue researching the subject. No patient returned asking to reverse the perineal colostomy for an abdominal colostomy. One of the most important testemony that a patient with perineal colostomy did in her 82 years of life and 20 years of perineal colostomy was: "I have privacy". She was admitted in 2010 to be operated from a bladder cancer.

Survival was not the main focus of the paper, as it depends on staging and prognosis of the tumor, the technical refinement of the surgeon and the surgical technique proposed. 


\section{CONCLUSION}

The technique of perineal colostomy meets the current goals of surgical treatment of rectal cancer that affects the sphincter: radical resection of the neoplasm offering neoanal function reconstitution with greater quality of life. There is great satisfaction of patients because this technique offers, in addition to the proposed curative intent, rehabilitation very close to the physiological condition of the human being ${ }^{16}$.

\section{REFERENCES}

1. Altomare D F, Rinaldi M, Martinelli E, Veglia A, Sallustio P. Perineal colostomy following Miles procedure: from reconstructive surgery to the artificial anal sphincter. Osp Ital Chir 2000; 6(6):572-77.

2. Allal AS et al. Sphincter-sparing surgery after preoperative radiotherapy for low rectal cancers: feasibility, oncologic results and quality of life outcomes. Br J Cancer 2000: 82(6):1131-7

3. Camilleri-Brennan J, Steele RJ. Objective assessment of morbidity and quality of life after surgery for low rectal cancer. Colorectal Dis: 2002 4(1):61-6621.

4. Cesaretti IUR, Santos VLCG, Vianna LAC. Qualidade de vida de pessoas colostomizadas com e sem uso de métodos de controle instestinal. Rev Bras Enferm, Brasília 2010 jan-fev; 63(1): 16-21.

5. Deoti B, Arantes RME, Campos CF, Hayck J, Lázaro da Silva A. Morphology and immunohistochemistry of the myenteric plexus of valves constructed in the colon of rats submitted to abdominoperineal amputation and perineal colostomy. Acta Cir Bras. 2013;28(4): 272-81

6. Deoti B, da Silva AL, Costa MZ, Dinali AC. Histological study of the left colon of rats after extra-mucosal seromyotomy (continent valves): evaluation of colonic emptying. Acta Cir. Bras. 2008; 23(3):230-36.

7. Goldsmith HS. Fecal control following pyloric valve transposition after abdominoperineal resection. Tech Coloproctol 2003; 7:95-101.

8. Gurusamy KS, Marzouk D, H. Benziger. A review of contemporary surgical alternatives to permanent colostomy International Journal of Surgery 2005; 3:193-205.

9. Heald RJ, Chir M, Smedh RK, Kald A, Sexton, Moran BJ. Abdominoperineal Excision of the Rectum - An Endangered Operation. Dis Colon e Rectum 1997; 40(7):747-51.

10. Lavery IC, Lopez-Kostner F, Fazio VW, Fernandez-Martin M, Mikom JW, Church JM. Chances of cure are not compromised with sphictersaving procedures for cancer of the lower third of the rectum. Surg 1997; $122: 779-85$.
11. Lázaro da Silva A. Tentativa de tratamento do "Dumping" através de um "esfincter" ileal. Rev Assoc Med Minas Gerais 1974; 25(1):32-33.

12. Lázaro da Silva A. Amputação abdominoperineal com colostomia perineal. Rev Bras Coloproct 1991; 11(3):105-8.

13. Lázaro da Silva A. Amputacion Abdominoperineal com colostomia perineal. Pren Med Argent 1993; 82:800-04.

14. Lázaro da Silva A. Abdominoperineal excision of the rectum and anal canal with perineal colostomy. Eur J Surg 1995; 161:761-64.

15. Lázaro da Silva A. Amputação abdominoperineal com colostomia perineal. Dia a Dia Gastroenterol 1997; 2(3): 22-3.

16. Lázaro da Silva A. Tratamento do câncer reto-anal. Colostomia perineal. Atheneu 1998; 1:1-206.

17. Miles WE. A method of performing abdomino-perineal excision for carcinoma of the rectum and of the terminal portion of the pelvic colon. Lancet 1908; 2:1812-13.

18. Oliveira JZ. Avaliação da qualidade de vida em pacientes submetidos à cirurgia de amputação abdominoperineal do reto com colostomia abdominal ou colostomia perineal, 2010 [Dissertação]. Botucatu: Universidade Estadual Paulista; 2010.

19. Sato T, Konishi F, Ueda K, Kashivagi H, Kanazawa K, Nagai H. Physiological anorectal reconstruction with pudendal nerve anastomosis and a colonic S-pouch after abdominperineal resection: report of 2 successful cases. Surg 2000; 128(1):116-120.

20. Siqueira SL, Lázaro da Silva A, Reis OAF, Fantauzzi RS, Silva Jr. OM, Sales PGO. Estudo de válvulas artificiais no cólon esquerdo após amputação abdominoperineal parcial do reto mais colostomia perineal, em cães. Arq Gastroenterol 2006; 43(2):125-31.

21. Silva Junior AL, Lázaro da Silva A, Castro LPF. Histopatologia da seromiotomia dupla e sutura seromuscular no cólon descendente de ratos. Rev Col Bras Cir 1999; 26(6):367-73.

22. Sprangers M.A.G., Velde A., Asronson N.K., The construction ans testing os the EORTC colorectal cancer-specific quality of life questionanaire module (QLQ-CR38). Eur J Cancer. 1999.

23. Valenti MT, Salabert SN, Borsot AG. Estudio comparative sobre los beneficios da la irrigación de la persona colostomizada: adaptación, confort y costes. Enfermería Clínica. 1999;9(1):7-12.

24. Veloso SG, Biet R, Rios MA. Leite VHR, Lázaro da Silva A. Eficácia da confecção de válvulas colônicas após ressecção retoanal em ratos. Rev Col Bras Cir 2001; 28(5):356-63.

25. Velitchkov NG, Kirov GK, Losanoff JE, et al. Abdominoperineal resection and perineal colostomy for low rectal cancer. The Lázaro da Silva Technique. Dis. Colon Rectum 1997; 40(5):530-3.

26. Velitchkov NG, Kirov GK, Losanoff JE, et al. Lázaro da Silva perineal colostomy after abdominoperineal resection of the rectum. 8th World Congress of the International Gastro-surgical Club 1998; 1:15-18. 